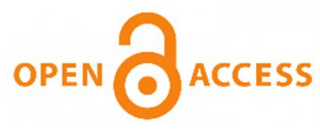

Authors' contribution:

A) conception and design of the study

B) acquisition of data

C) analysis and interpretation of data

D) manuscript preparation

E) obtaining funding

\section{Social support and sports participation motivations of female adolescents in India - study of age transition and achievement level}

\author{
Md. Dilsad Ahmed ${ }^{1 \mathrm{~A}-\mathrm{D}}$ (iD), Walter King Yan $\mathrm{Ho}^{2 \mathrm{D}-\mathrm{E}}$, Rudolph \\ Leon Van Niekerk ${ }^{3 C-D}$ (iD), Lauren Sulz ${ }^{4 D}$ (iD, Shaheen \\ Begum $^{5 B}$ \\ ${ }^{1}$ Oregon State University, USA \\ ${ }^{2}$ University of Macau, Macau, China \\ ${ }^{3}$ Fort Hare University, South Africa \\ ${ }^{4}$ University of Alberta, Canada \\ ${ }^{5}$ Savitribai Phule Pune University, India
}

ABSTRACT

Motivation is likely a pivotal factor contributing to sports participation. In India, because of the unsupportive sports/physical education environment, girls participate less in sports and other physical activities than boys. Therefore, embedding a planned healthy environment with good social support may maximize and, consequently, increase their participation in various sports and physical activities. Considering this unabated dialogue and assuming that motivation is a pivotal need for female sports participation, this study examined the differences in motivation to participate in sports among female adolescents across three age categories: early (11-14 years old), middle (15-18 years old), and late (19-21 years old) adolescence. A total of 528 female adolescents from Assam, India participated in the study. Participation in physical education courses was the criterion for the participants, and they were invited to complete the Participation Motivation Questionnaire. A factor analysis with direct oblimin rotation using the maximum likelihood extraction method yielded a 23-item, five-factor structure that exhibited moderate internal consistency. An ANOVA revealed significant differences across all three age categories regarding all the extracted factors. Moreover, t-tests of all sub-factors identified significant differences between the two achievement levels of district-level and inter-district-level athletes. This study provides sound psychometric and comparative results that are useful for education and formative reviews in applied settings and research purposes. It also serves as a measurement tool for embedding motivation to participate in physical activities and sports among female adolescents and the development of strategic ideas to assist female adolescents from less privileged areas to experience healthy growth and a healthy lifestyle.

KEYWORDS achievement 


\section{Introduction}

The growing tendency toward sedentary behavior, which contributes to the increased prevalence of diabetes and various non-communicable diseases, has a significant effect on the gross national economy (Yesudian et al., 2014), people's quality of life (Verma \& Dadarwal, 2017), and their well-being (Mercer, 2012; Debono, 2007). Related to the issue of sedentary behavior is the continuous decline in sports participation, especially among female adolescents, which has sparked debate among researchers (Eime et al., 2016; Scheerder, 2006; Strong et al., 2005). Researchers have struggled to find strategies to comprehend this problem, including conditions underpinning obesity and the hindrances it causes (Strong et al., 2005; Sherar, 2007; Australian Institute of Health and Welfare, 2010; Nielse et al., 2011).

Numerous studies have shown the benefits of regular participation in physical activity and sport, which significantly reduces the prevalence of various non-communicable diseases (Stalmatakis \& Weiler, 2010; Ahmed et al., 2017, 2016; Sánchez et al., 2016). This study takes a look at the case of India; female adolescents from Assam were invited to participate in the research. India has the world's largest population of people between the ages of 10 and 24 years old (United Nations, Department of Economic and Social Affairs, Population Division, 2015). Yet, the subject of physical or sports education is not a well-respected subject in school teaching (Khandare, 2016; Singh, 2016). There are no concrete efforts to organize young people and encourage them to engage in playful competition. Sports participation remains a highly neglected area in schools (Khandare, 2016). The participation of females in sports comes to our attention in particular, as this is the area with the weakest support in this country. This research was conducted in the state of Assam, a state in northeastern India that is situated south of the eastern Himalayas. Bhandari and Chakraborty (2014) comment that the per capita income of Assam is among the lowest in the country, and it is estimated that its poverty rates are high in rural areas compared to urban areas. This research focuses on female adolescents in India in the Assam region. The findings may offer insight for assisting female adolescents from this less privileged area to be active. There is a long history on the development of feminism or gender studies in the West, but many parts of the world are not covered in this history (Pfister, 2017). It is important to conduct research on female adolescents in areas with economic or social difficulties and send a clear message that they have not been forgotten. Doing so will also help convey concrete strategies for how the system can address the issue of positive health outcomes for female youth. Health psychologists may have the knowledge to identify factors associated with female youth participation in organized sports and physical activity. The result may also be beneficial to not only the physical, social, and psychological development of females, but also their achievement-related and improved self-esteem and self-identity (Ahmed et al., 2014).

\section{A conceptual understanding of sports and physical education in the Indian education system}

Physical education (PE) is a non-compulsory subject in India. Nevertheless, it is necessary to have some further context in order to fully understand this statement. In practice, schools such as those enlisted in the Central Board of Secondary Education (CBSE), Indian Certificate of Secondary Education (ICSE), and Indian State Boards must offer PE as a subject in the curriculum. It is not compulsory for schools to implement this subject. The offering of this subject and PE attendance is sometimes purely the choice of the school or individual student, as most schools do not show interest in this subject and the students follow suit. Although it is not compulsory for students to participate in PE, schools located in urban areas are more likely to offer PE than those in rural and semi-rural areas. Participants in this research study were recruited from schools in the Assam region where PE is included as a formal subject in the academic curriculum. PE is defined as a "formal subject" in this study as it shares a similar status with the main curricular subjects (e.g., similar to math, science, and English). Additionally, the schools involved in the investigation have appointed and certified PE teacher(s) who deliver the PE curriculum. The PE departments of these schools provide opportunities for students to participate in various sports tournaments conducted by district sports offices and other associations/federations. 
Historically, since the beginning of Indian civilization, women have faced discrimination and have been in a disadvantaged position in society. Thus, they have rarely participated in games, sports, or other community health-related activities (Guttman, 1991). The current situation has resulted in few improvements. India is still a male-dominated society in many areas. In fact, despite having a female population of more than 1.2 billion, few female sports icons represent India or strive to enhance the country's presence in various international competitions. While many countries are considering the globalization of sports, Indian professionals are encountering the challenge of adopting PE as a compulsory subject in schools. Problems associated with PE directly and indirectly lower children's level of motivation to participate in physical activity and sports. Among these problems are Indians' many misconceptions of PE, including the following: PE is considered a rest period between academic classes; PE can be used for completing homework in other subjects; and only academically weak (unintelligent) students opt to take this subject. Misconceptions specific to female participation in PE are: PE negatively affects girls' reproductive organs during pregnancy; girls lose their virginity when taking PE; PE may disfigure their bodies; PE involves masculine tasks and girls should be confined to home activities and display taciturn behaviors; and participation in PE allows girls to have more contact/communication with boys and thus confuses their feelings towards marriage (Husan, 2015; Abder-Rahman, 2009; United Nations Division for the Advancement of Women, Department of Economic and Social Affairs, 2007). PE is rarely recognized as a foundational course in schools that contributes to the overall development of the mind and body of the student.

\section{Aims of the study}

Sports participation is a personal choice among Indian children, as they rarely receive external motivation that increases their desire to participate in sports, given the unsupportive environment (Husan, 2015; Layak \& Aravind, 2017). Such an environment is created by the fact that PE is a non-compulsory subject and does not have equal status with other subjects. A literature review shows that self-motivation is positively related to sustaining students' participation in physical activity and sports (Calvo et al., 2010; Teixeira et al., 2012). Moreover, this research emphasizes that the reasons for participating (or not participating) in sports are multiple and diverse (Fraser-Thomas et al., 2008; Murcia et al., 2010; Beni et al., 2017). Sustaining children's level of motivation is important and depends on their experience participating in sports activities, including whether or not they had fun, developed skills, learned something, spent time with friends, experienced success, and improved their health (Murcia et al., 2010). Sherar et al. (2007) reveal that physical activity levels decrease as age increases. Iannotti et al. (2012) examined students aged 11, 13, and 15 years old across seven countries and found that the association between physical activity and health motivation varied significantly by region and gender. In fact, experiencing enjoyment and achieving goals through sports are unique features of quality PE (Ho et al., 2017a, 2018, 2019a, 2019b). Similarly, enjoying participation in sports activates positive feelings, such as pleasure (Beni et al., 2017). Therefore, this study investigates the differences in adolescent females' motivation to participate in sports among multiple age groups and levels of achievement. The area of Assam is selected in this study as the research team expects to determine the best strategy for assisting female adolescents from less privileged areas so that they may experience healthy growth and a healthy lifestyle.

\section{Theoretical background}

Matsumoto and Takenaka (2004) highlight the important role of motivation required for both recreational and competitive sports. Motivation is considered a predictor of future involvement in sports (Iso-Ahola \& St. Clair, 2000). In addition to various health benefits, motivation is defined as a strong desire, wish, or powerful stimulus that comes from within a person to propel him/her towards achieving a goal.. Self-determination theory (SDT; Deci \& Ryan, 1985, 2000) is a motivational framework based on people's three psychological needs: perception of competence, relatedness, and autonomy (Deci \& Ryan, 1985). These needs are closely related to intrinsic 
motivation and psychological health. The perception of competence signifies one's personal capabilities. Autonomy indicates one's own needs and value system. Relatedness reflects one's perceptions of personal connections, thereby creating an individual's interpersonal environment (Deci \& Ryan, 1985). SDT assumes that motivation for sports participation is multidimensional and, as such, consists of intrinsic, extrinsic, and motivational factors (Deci \& Ryan, 1985). Research on SDT areas (e.g., PE, sports, exercise, and physical activities) that examines individuals' basic needs has recently garnered significant interest (Pedro et al., 2012; Fortier et al., 2007; Silva et al., 2006). SDT (Deci \& Ryan, 1985) and the achievement goal theory (AGT; Nicholls, 1989) frameworks have been applied successfully to the contexts of physical activity and sports engagement among different age groups, including youth and adults (Fenton et al., 2017; Ahmed et al., 2016; Ho et al., 2017b, 2019c). Bosnar and Balent (2009) found that motivation is associated with multiple engagement motives and different types of motivation. Moreover, SDT has been applied successfully to intervention research within the PE context to manipulate the psychological needs of youth, thereby increasing specific targeted behaviors such as physical activity, PE enjoyment, and a sense of autonomy (Lonsdale et al., 2013, 2009; Ward et al., 2008). For girls specifically, researchers have highlighted the need for relatedness as an important aspect in their physical activity participation and engagement in PE (Pfaeffli \& Gibbons, 2010; Shen et al., 2012). For example, Shen et al. (2012) reported that girls with a high sense of relatedness (including their connections to teachers and peers) were more likely to show enthusiastic participation and effort in PE class.

\section{Hypothesis formulation based on the literature review}

Research on sports motivation is rare in India, and results on female sports motivation are inconclusive. Piri et al. (2014) observed 350 male and female students and found that the level of motivation towards sports participation was higher among the latter than the former. Similarly, Bastos, Gonzalez, and Marquez (2006) examined 100 male and 130 female Brazilian adults and revealed that the latter were more associated with aesthetic and health motivations, whereas the former participated for social reasons. Significant increases in health interest (Sherar et al., 2008) and psychological perspectives (Clark et al., 2011) have been related to the active sports participation of children and adolescents. This identified interest in such a pursuit highlights the decreasing level of physical activity and sports participation with age, particularly during adolescence among females compared with their male counterparts (Trost et al., 2008; Whitehead \& Biddle, 2008). Surprisingly, the World Health Organization (World Health Organization, 2008) found that 11- to 15-year-old girls are less active than their male counterparts. The transition of children from primary to secondary school is a crucial stage that influences sports participation significantly. However, fewer studies have investigated factors that deter them from continuous involvement in health and health-promoting activities (Humbert et al., 2008). In conjunction, motivation is a strong predictor of the active enhancement of youth involvement in sports. Therefore, sports psychologists have investigated motives behind sports participation to reduce high dropout rates (Sarrazin, Boiché, \& Pelletier, 2007). The Environment, Communications, Information Technology and the Arts References Committee (2006) revealed that a 50\% dropout rate from sports occurs between 5 and 10 years of age among girls. However, existing literature has shown that children have yet to obtain the desired health benefits and enjoyment based on their participation (Lutz et al., 2008; Strel \& Sila, 2010), which warrants future research to understand the different reasons for participating in and withdrawing from sports and physical activity (Kondrič et al., 2013). Bauman et al. (2009) indicated that male students reported higher levels of physical activity than their female counterparts in 17 of 20 countries studied. The prevalence of low physical activity ranged from $7 \%$ to $41 \%$ among males and from $6 \%$ to $49 \%$ among females.

Therefore, this study hypothesized that: $\mathrm{H}_{1}$ : Significant differences in motivation to participate in sports activities exist across all age categories; $\mathrm{H}_{2}$ : Significant differences in motivation to participate exist across students with different levels of achievement, namely, district-level (DL) vs. inter-district level (IDL). The 
three-fold task of this study was to establish the 1) latent structure of athletes' motivational types, 2) differences in motivation to participate in sports activities among female adolescents from three age categories, and 3) differences in motivation to participate in sports activities based on level of achievement.

\section{Methods}

\section{Participants}

Institutional permission to conduct this study was obtained. Data were collected from schools where PE was presented as a formal subject. A stratified random sample of 528 female adolescents (age: $16.72 \pm 0.617$ ) from different schools in Assam, India participated in this study. The sample was stratified across participants' choice to attend PE classes at the various institutions. Participants were also members of various sports clubs, including cricket $(\mathrm{n}=127,24.1 \%)$, football $(\mathrm{n}=65,12.3 \%)$, badminton $(\mathrm{n}=36,6.8 \%)$, lawn tennis $(\mathrm{n}=68,12.9 \%)$, swimming $(n=89,16.9 \%)$, and athletics $(n=143,27.1 \%)$. These individuals regularly participated in schoollevel tournaments conducted by the district office under the Directorate of Sports in Assam. Participants were categorized into three age groups according to Steinberg's (1993) developmental approach to adolescents: early adolescence (11-14 years old), middle adolescence (15-18 years old), and late adolescence (19-21 years old).

Table 1 presents descriptive statistics of the age categories, including number of participants in each category and means and standard deviations of age groups for female participants and the total sample. Data were collected during a PE class for each group.

Table 1. Descriptive statistics of the age categories: Early, middle, and late adolescence

\begin{tabular}{lccc}
\hline \multicolumn{1}{c}{ Age Categories } & Number of female athletes & Age Mean \pm SD \\
\cline { 3 - 4 } & & & Mean \pm SD \\
\hline Early Adolescent Students (11-14 years) & 173 & $(32.8 \%)$ & $13.32 \pm .755$ \\
Middle Adolescent Students (15-18 years) & 190 & $(36 \%)$ & $17.40 \pm .453$ \\
Late Adolescent Students (19-21 years) & 165 & $(31.2 \%)$ & $19.51 \pm .817$ \\
Total & 528 & $(100 \%)$ & $16.72 \pm 2.61$ \\
\hline
\end{tabular}

\section{Instruments}

This study used Gill et al.'s (1983) 30-item Participation Motivation Questionnaire (PMQ). The PMQ has been used widely in several studies on motives for participation in youth sports. Participants completed the PMQ (Gill et al., 1983), which includes lists of possible reasons for students' participation in sports. Respondents used a 5-point Likert scale, ranging from 1 (not at all important) to 5 (extremely important) to respond to items, such as "I participate in sports because it is..."

Results from a factor analysis of the PMQ revealed that achievement/status, team atmosphere, fitness, energy release, skill development, friendship, and fun are basic motives for student participation in sports activities (Gill et al., 1983). Zahariadis et al. (2005) identified six motivational factors as reasons for students to engage in physical activities (Kondrič, et al., 2013). These reasons are skill development and competition (Cronbach's $\alpha$ reliability $=0.89)$, status/recognition $(\alpha=0.85)$, energy release $(\alpha=0.77)$, team atmosphere $(\alpha=0.82)$, friendship and social interaction $(\alpha=0.63)$, and fitness $(\alpha=0.83)$. Kondrič, et al., (2013) found six factors that motivate adolescents to participate in sports activities: sports activities with friends $(\alpha=0.868)$, popularity $(\alpha=$ $0.877)$, fitness and health $(\alpha=0.856)$, social status $(\alpha=0.765)$, sports events $(\alpha=0.568)$, and relaxation $(\alpha=$ $0.572)$. 


\section{Data analyses}

Data were analyzed using the IBM SPSS (20.00). Basic descriptive statistics (i.e., means, standard deviations, and frequencies) were calculated. A factor analysis using the maximum likelihood method with direct oblimin rotation was performed for all PMQ items. A one-way ANOVA was performed to determine the differences among students based on three age categories - early (11-14 years old), middle (15-18 years old), and late (1921 years old) adolescence - for each of the factors identified via the factor analysis. Mean comparisons of age categories were determined using a one-way ANOVA and Scheffé's post-hoc test for unequal samples to gain insight into the individual differences among students of different institutions with regard to the motivational structure of participating in a physical activity (sport). Moreover, t-tests were computed to examine the differences between levels of achievement.

\section{Results}

Table 2 shows the descriptive statistics (means and standard deviations) for each item on the PMQ for each age group and the total sample. Motives for participating in physical activity that stood out were items 15-17: participants' enjoyment of exercise $(2.08 \pm 0.643)$, having something to do $(2.10 \pm 0.645)$, and the action it provides $(2.11 \pm 0.640)$. However, because an analysis at the item level was too broad and did not provide synthesis, a factor analysis was conducted on all items to reduce them to their underlying structure.

Table 2. Descriptive statistics for all by age category according to the Participation Motivation Questionnaire

\begin{tabular}{|c|c|c|c|c|c|}
\hline \multirow[t]{2}{*}{ No. } & \multirow[t]{2}{*}{ Description of the items } & $\begin{array}{c}\text { Early } \\
\text { 11-14 years } \\
(n=173)\end{array}$ & $\begin{array}{c}\text { Middle } \\
\text { 15-18 years } \\
(n=190)\end{array}$ & $\begin{array}{c}\text { Late } \\
\text { 19-21 years } \\
(n=165)\end{array}$ & $\begin{array}{c}\text { Total Sample } \\
\qquad(\mathrm{N}=\mathbf{5 2 8}) \\
\end{array}$ \\
\hline & & Mean \pm SD & Mean \pm SD & Mean \pm SD & Mean \pm SD \\
\hline 1 & I want to improve my skills & $1.62 \pm .593$ & $1.45 \pm .670$ & $1.37 \pm .485$ & $1.48 \pm .600$ \\
\hline 2 & I want to be with my friends & $1.31 \pm .525$ & $1.36 \pm .544$ & $1.46 \pm .546$ & $1.37 \pm .541$ \\
\hline 3 & I like to win & $1.19 \pm .440$ & $1.24 \pm .467$ & $1.40 \pm .560$ & $1.27 \pm .496$ \\
\hline 4 & I want to get rid of energy & $1.15 \pm .379$ & $1.17 \pm .435$ & $1.32 \pm .495$ & $1.21 \pm .444$ \\
\hline 5 & I like to travel & $1.18 \pm .431$ & $1.15 \pm .402$ & $1.31 \pm .491$ & $1.21 \pm .445$ \\
\hline 6 & I want to stay in shape & $1.18 \pm .418$ & $1.21 \pm .457$ & $1.44 \pm .608$ & $1.27 \pm .511$ \\
\hline 7 & I like the excitement & $1.47 \pm .624$ & $1.32 \pm .521$ & $1.45 \pm .609$ & $1.41 \pm .587$ \\
\hline 8 & I like the teamwork & $1.57 \pm .620$ & $1.38 \pm .529$ & $1.52 \pm .590$ & $1.49 \pm .584$ \\
\hline 9 & My parents or close friends want me to play & $1.43 \pm .531$ & $1.34 \pm .509$ & $1.45 \pm .619$ & $1.41 \pm .554$ \\
\hline 10 & I want to learn new skills & $1.45 \pm .554$ & $1.40 \pm .552$ & $1.53 \pm .619$ & $1.46 \pm .576$ \\
\hline 11 & I like to meet new friends & $1.40 \pm .537$ & $1.37 \pm .536$ & $1.47 \pm .649$ & $1.41 \pm .575$ \\
\hline 12 & I like to do something I'm good at & $1.38 \pm .498$ & $1.30 \pm .470$ & $1.47 \pm .569$ & $1.38 \pm .516$ \\
\hline 13 & I want to release tension & $1.54 \pm .574$ & $1.35 \pm .491$ & $1.55 \pm .628$ & $1.48 \pm .570$ \\
\hline 14 & I like the rewards & $1.31 \pm .536$ & $1.44 \pm .638$ & $1.62 \pm .637$ & $1.46 \pm .617$ \\
\hline 15 & I like to get exercise & $2.10 \pm .575$ & $2.09 \pm .691$ & $2.04 \pm .656$ & $2.08 \pm .643$ \\
\hline 16 & I like to have something to do & $2.13 \pm .553$ & $2.15 \pm .714$ & $2.00 \pm .643$ & $2.10 \pm .645$ \\
\hline 17 & I like the action & $2.13 \pm .563$ & $2.12 \pm .693$ & $2.07 \pm .653$ & $2.11 \pm .640$ \\
\hline 18 & I like the team spirit & $1.73 \pm .681$ & $1.90 \pm .659$ & $1.93 \pm .659$ & $1.85 \pm .671$ \\
\hline 19 & I like to get out of the house & $2.02 \pm .570$ & $1.94 \pm .631$ & $1.98 \pm .666$ & $1.98 \pm .623$ \\
\hline 20 & I like to compete & $1.99 \pm .575$ & $1.98 \pm .755$ & $1.87 \pm .606$ & $1.95 \pm .656$ \\
\hline 21 & I like to feel important & $1.91 \pm .575$ & $2.03 \pm .704$ & $1.87 \pm .606$ & $1.94 \pm .636$ \\
\hline 22 & I like being on a team & $1.92 \pm .517$ & $1.96 \pm .733$ & $1.89 \pm .640$ & $1.93 \pm .639$ \\
\hline 23 & I want to go on to a higher level & $1.98 \pm .533$ & $2.06 \pm .659$ & $1.81 \pm .649$ & $1.96 \pm .625$ \\
\hline 24 & I want to be physically fit & $2.02 \pm .564$ & $1.98 \pm .617$ & $1.83 \pm .659$ & $1.95 \pm .618$ \\
\hline 25 & I want to be popular & $1.42 \pm .581$ & $1.26 \pm .497$ & $1.07 \pm .260$ & $1.25 \pm .489$ \\
\hline 26 & I like the challenge & $1.06 \pm .244$ & $1.16 \pm .375$ & $1.25 \pm .450$ & $1.16 \pm .372$ \\
\hline 27 & I like the coaches or instructors & $1.12 \pm .351$ & $1.24 \pm .497$ & $1.38 \pm .511$ & $1.24 \pm .470$ \\
\hline 28 & I want to gain status or recognition & $1.08 \pm .282$ & $1.21 \pm .460$ & $1.22 \pm .446$ & $1.17 \pm .410$ \\
\hline 29 & I like to have fun & $1.11 \pm .320$ & $1.17 \pm .419$ & $1.20 \pm .416$ & $1.16 \pm .389$ \\
\hline 30 & I like to use the equipment or facilities & $1.13 \pm .346$ & $1.13 \pm .401$ & $1.17 \pm .397$ & $1.14 \pm .382$ \\
\hline
\end{tabular}


To define the latent motivational structure of all respondents in a better way, a maximum likelihood analysis (factor analysis) with a direct oblimin rotation was used. A high Kaiser-Meyer-Olkin measure of sampling adequacy (MSA) value (0.863) and a significant Bartlett's test of sphericity (approximate chi-square 4774.957, $\mathrm{df}=253, \mathrm{p}<0.001)$ confirmed the factorability of the items. Several criteria, including the differences between adjacent eigenvalues, a scree plot, and differences in the percentage of variance explained, were used to determine the number of factors (Table 3). Five significant factors that explained $50.23 \%$ of the variance were extracted. The purpose was to account for the adjacent factors and, more importantly, to consider the factor structure.

\section{Underlying structure of athletes' motivation to participate}

The MSA is an index used to quantify the degree of inter-correlation among items and appropriateness of factor analysis. A value above 0.50 for either the entire matrix or an individual variable indicates the appropriateness of acceptance (Field, 2000). The results of the factor analysis are presented in Table 3. All items with factor loadings greater than 0.50 were retained. When the pattern matrix (factor and structure matrices were considered because of cross-loading) was considered, four subscales were determined as retaining and reflecting the conceptual framework. Of the 30 items, 7 with low factor loadings were excluded from the analysis. Therefore, the original set of 30 items was reduced to 23 items, which are listed in Table 3 for reference.

All factors showed acceptable to high internal consistency with Cronbach's alpha scores between 0.754 and 0.865. Factor 1 (i.e., sports action with friends) had a high eigenvalue (5.81) and explained $25.27 \%$ of the variance. Items in this factor expressed enjoyment from exercise and pleasure with having an active lifestyle with friends. The main projections of the statements offered in the questionnaire regarding this factor were related to action and friendship. This factor included motives such as "I like the teamwork," "My parents or close friends want me to play," "I like to meet new friends," and "I want to be with my friends."

Factor 2 (i.e., fitness and health) explained $15.35 \%$ of the variance and had a high eigenvalue (3.27). Items in this factor expressed the enjoyment achieved from fitness and various health consequences associated with exercise. This factor was defined by intrinsic motives related to good health and included items such as "I like to have something to do," "I like to exercise," and "I like action." Both intrinsic and extrinsic motivations contribute to this factor because student athletes are motivated by competition and social approval (Bosnar \& Balent, 2009).

Items in factor 3 (i.e., social status) expressed enjoyment from participation in physical activity and associated social recognition. Factor 3 had an eigenvalue of 2.08 and explained $9.05 \%$ of the variance. It was defined by statements such as "I like to have fun," "I like to use the equipment or facilities," and "I want to gain status or recognition."

Items in factor 4 (i.e., popularity) expressed the feelings of importance associated with performance and success in physical activity. This factor referred to the sense of importance that physically active people achieve through sports, such as "I like to feel important," "I want to go on to a higher level," "I like being on a team," "I like to compete," "I like to get out of the house," and "I want to be physically fit." It explained 5.98\% of the variance and had an eigenvalue of 1.37 .

The last factor (i.e., energy release) explained $4.88 \%$ of the variance and had an eigenvalue of 1.12 . This factor was defined by statements such as "I like to travel," "I want to stay in shape," and "I want to get rid of energy."

The PMQ was adapted and administered to participants in various sports fields (Trembath et al., 2002), athletes (Kondrič, 2013), participants in various physical activities (Kolt et al., 2004), and students in PE settings (Zahariadis \& Biddle, 2000). Hence, the number of factors and component items identified through the factor analysis have varied levels of dependency on the sample under investigation (Gill et al., 1983). This conclusion is evident in this study. 
Moreover, factor 1 (sports action with friends) recorded the highest mean (12.92 \pm 3.54$)$, indicating that students perceived it as the most important motivation for physical activity in developing quality PE programs. Factor 4 (popularity, $9.74 \pm 2.33$ ) and factor 2 (fitness and health, $6.29 \pm 1.68$ ) came next. Factor 5 (energy release, 3.70 \pm 1.18 ) and factor 3 (social status, $3.48 \pm 0.968$ ) had the lowest mean scores, indicating that they were perceived to be less important motivating factors than the three aforementioned factors.

Table 3. Factor structure of the Participation Motivation Questionnaire for students from three age categories of the adolescent period (Maximum Likelihood, Direct Oblimin Rotation)

\begin{tabular}{|c|c|c|c|c|c|c|c|}
\hline Items & Description of the items & $\begin{array}{c}\text { Factor } 1 \\
\text { Sports } \\
\text { Action } \\
\text { with } \\
\text { Friends } \\
\end{array}$ & $\begin{array}{c}\text { Factor } 2 \\
\text { Fitness and } \\
\text { Health }\end{array}$ & $\begin{array}{c}\text { Factor } 3 \\
\text { Social } \\
\text { Status }\end{array}$ & $\begin{array}{c}\text { Factor } 4 \\
\text { Popularity }\end{array}$ & $\begin{array}{l}\text { Factor } 5 \\
\text { Energy } \\
\text { Release }\end{array}$ & \\
\hline & & 1 & 2 & 3 & 4 & 5 & $h$ \\
\hline Item8 & I like the teamwork & .695 & & & & & .302 \\
\hline Item12 & I like to do something I'm good at & .667 & & & & & .483 \\
\hline Item 10 & I want to learn new skills & .665 & & & & & .599 \\
\hline Item 13 & I want to release tension & .660 & & & & & .658 \\
\hline Item9 & $\begin{array}{l}\text { My parents or close friends want me } \\
\text { to play }\end{array}$ & .609 & & & & & .486 \\
\hline Item 7 & I like the excitement & .587 & & & & & .517 \\
\hline Item 1 & I want to improve my skills & .566 & & & & & .487 \\
\hline Item11 & I like to meet new friends & .553 & & & & & .550 \\
\hline Item2 & I want to be with my friends & .455 & & & & & .401 \\
\hline Item16 & I like to have something to do & & .860 & & & & .510 \\
\hline Item 15 & I like to get exercise & & .782 & & & & .498 \\
\hline Item17 & I like the action & & .738 & & & & .654 \\
\hline Item 29 & I like to have fun & & & .780 & & & .741 \\
\hline Item30 & $\begin{array}{l}\text { I like to use the equipment or } \\
\text { facilities }\end{array}$ & & & .719 & & & .586 \\
\hline Item 28 & I want to gain status or recognition & & & .645 & & & .400 \\
\hline Item 21 & I like to feel important & & & & .742 & & .532 \\
\hline Item 23 & I want to go on to a higher level & & & & .706 & & .413 \\
\hline Item 22 & I like being on a team & & & & .651 & & .505 \\
\hline Item24 & I want to be physically fit & & & & .556 & & .357 \\
\hline Item 20 & I like to compete & & & & .537 & & .436 \\
\hline Item5 & I like to travel & & & & & .679 & .611 \\
\hline Item6 & I want to stay in shape & & & & & .655 & .536 \\
\hline Item4 & I want to get rid of energy & & & & & .567 & .290 \\
\hline & Factor mean & 12.92 & 6.29 & 3.48 & 9.74 & 3.70 & \\
\hline & Factor standard deviation & 3.54 & 1.68 & .968 & 2.33 & 1.18 & \\
\hline & Cronbach's alpha & .865 & .844 & .754 & .786 & .801 & \\
\hline & Scale variance & 12.57 & 2.83 & .937 & 5.43 & 1.41 & \\
\hline & Eigenvalues & 5.81 & 3.53 & 2.08 & 1.37 & 1.12 & \\
\hline & Variance explained (\%) & 25.27 & 15.35 & 9.05 & 5.98 & 4.88 & \\
\hline & Items & 9 & 3 & 3 & 5 & 3 & \\
\hline
\end{tabular}

Extraction Method: Maximum Likelihood.

Rotation Method: Oblimin with Kaiser Normalization. a. Rotation converged in 11 iterations.

The results of the factor analysis indicated that the 23 items on the final version of the questionnaire demonstrated sound and satisfactory inter-correlation results. The inter-correlations among the four factors are presented in Table 4. All factors showed weak correlations with one another, ranging from -0.026 to 0.501 , with an average of 1.25, suggesting that the identified motivation factors were relatively independent of each other. The high reliability scores (i.e., internal consistency) for all factors indicated that the items were consistent 
within each factor and the factors were consistent within the model, thereby permitting additional meaningful analysis.

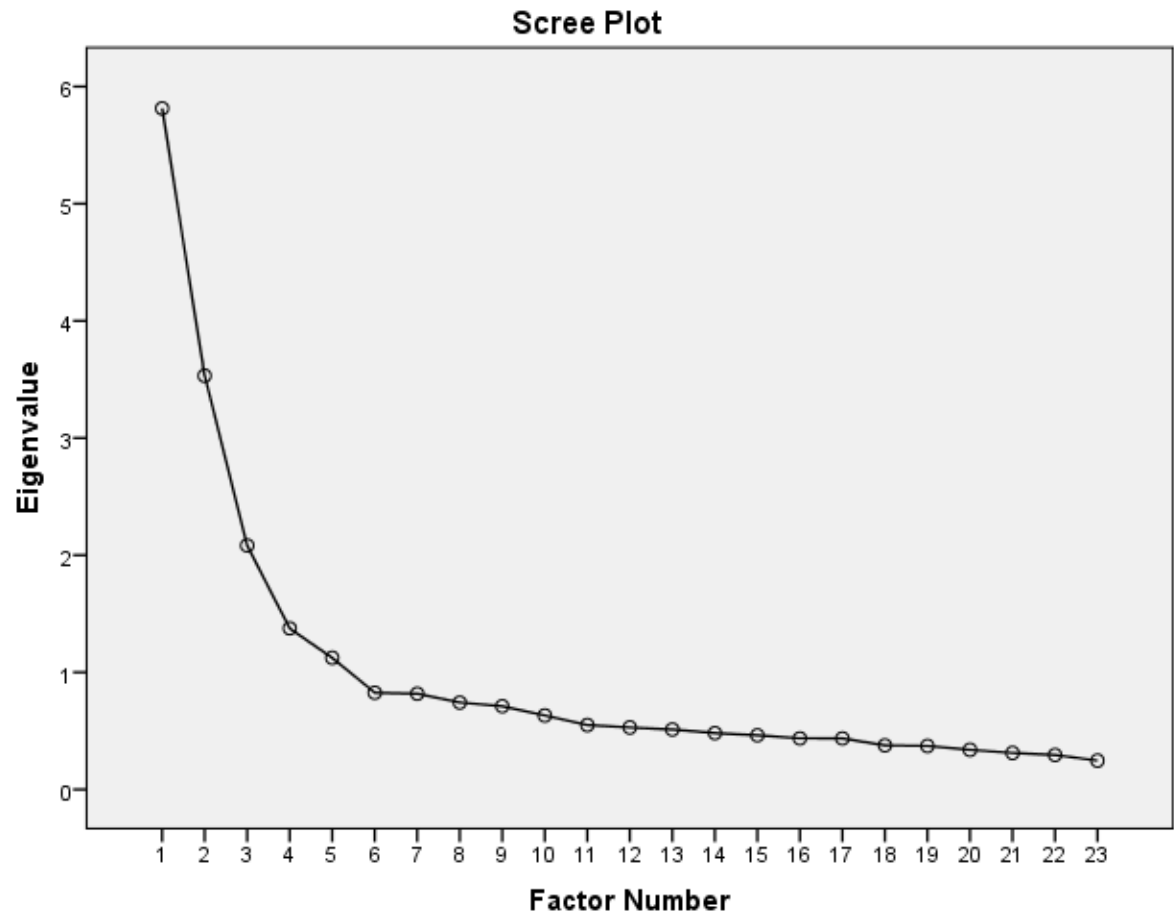

Figure 1. Scree plot depiction

A confirmatory factor analysis (CFA) using AMOS 21.00 (IBM) was conducted to examine the retained fivefactor structure from the exploratory factor analysis. The same dataset was used to determine the robustness of the analysis process, the psychometric properties of the retained factors, and the excluded items (Byrne \& Watkins, 2003). The overall model fit was evaluated using multiple goodness-of-fit indices, including the chisquare value, comparative fit index (CFI), Bentler-Bonett normed fit index (NFI), parsimony comparative fit index (PCFI), and root mean square error of approximation (RMSEA), using a 90\% confidence interval ( $90 \%$ CI). Although much debate surrounds the selection of precise thresholds of fit, which is especially relevant within the field of theory-based multi-item/factor CFA testing (see Marsh, Hau, \& Wen, 2004), thresholds greater than 0.90, close to or less than 0.08 (Bentler, 1995), and up to 0.08 (Browne \& Cudeck, 1993; Bollen, 1989) are commonly accepted for CFI and RMSEA as indicative of acceptable model fit.

Table 4. Factor correlation matrix

\begin{tabular}{|c|c|c|c|c|c|c|}
\hline & Factor & 1 & 2 & 3 & 4 & 5 \\
\hline 1 & Sports Action with Friends & 1.000 & .050 & .032 & .300 & .475 \\
\hline 2 & Fitness and Health & & 1.000 & -.030 & .501 & -.096 \\
\hline 3 & Social Status & & & 1.000 & .027 & .018 \\
\hline 4 & Popularity & & & & 1.000 & -.026 \\
\hline 5 & Energy Release & & & & & 1.000 \\
\hline
\end{tabular}

Extraction Method: Maximum Likelihood.

Rotation Method: Oblimin with Kaiser Normalization. 


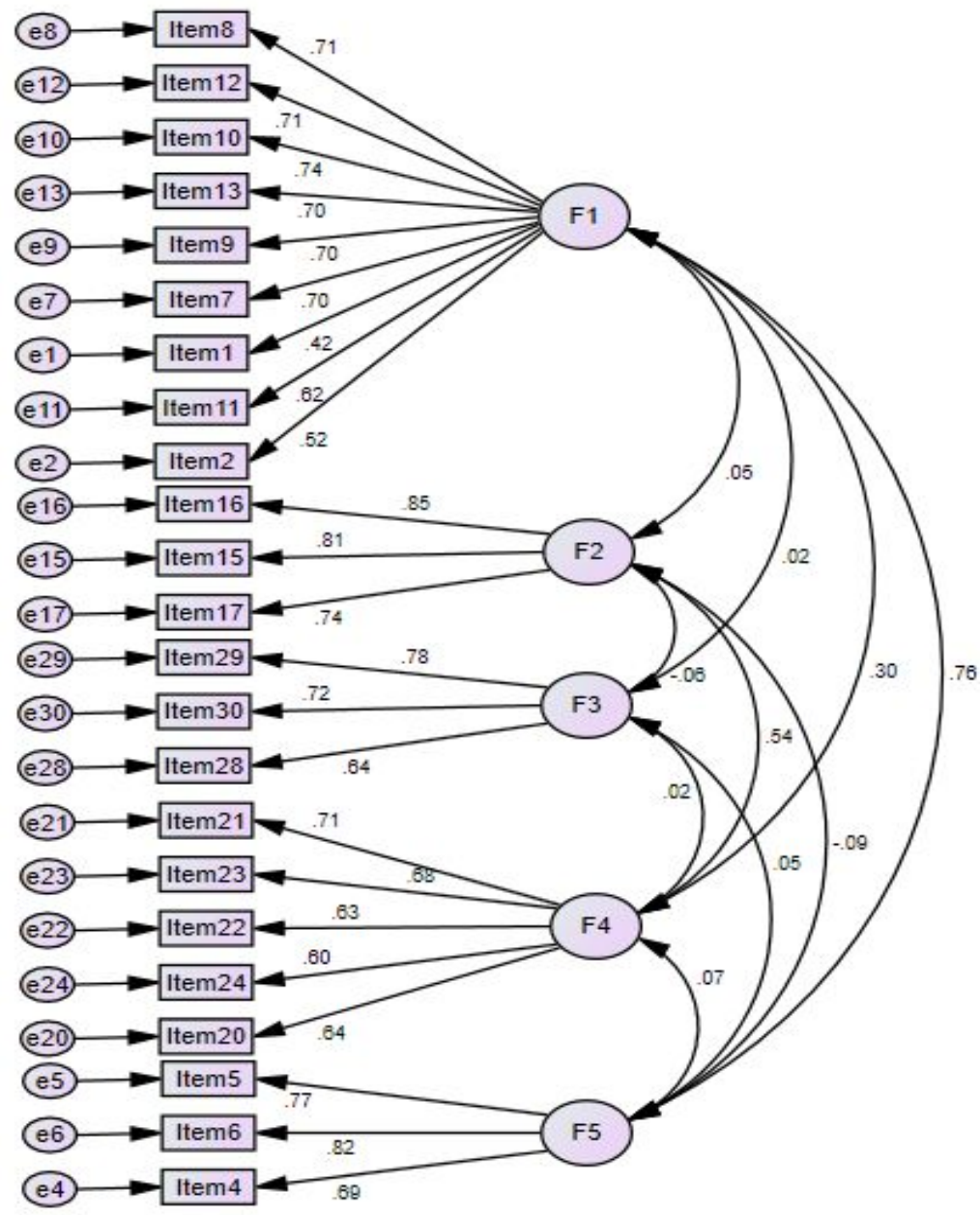

Figure 2. Measurement model

Note: Factor 1: Sports Action with Friends; Factor 2: Fitness and Health; Factor 3: Social Status; Factor 4: Popularity; and Factor 5: Energy Release.

To verify the retained factors' item loadings, a measurement model was evaluated using multiple goodness-offit indices, including the chi-square value, CFI, NFI, PCFI, and RMSEA, using a 90\% confidence interval (90\% CI). The results of the robust CFA using the maximum likelihood estimation method (see Table 5) suggested that the five-factor model provided an adequate fit to the data.

Table 5. Model fit indices for data collected using the PMQ

\begin{tabular}{lc}
\hline Properties & Model H0 \\
\hline $\mathrm{N}$ & 528 \\
$\mathrm{CMIN}$ & 575.200 \\
$\mathrm{DF}$ & 220 \\
$\mathrm{CMIN} / \mathrm{DF}$ & 2.615 \\
$\mathrm{CFI}$ & .922 \\
$\mathrm{TLI}$ & .903 \\
$\mathrm{NFI}$ & .881 \\
PCFI & .735 \\
RMSEA & .054 \\
\hline
\end{tabular}


Table 6. Age group (early, middle, and late adolescence) (ANOVA) differences regarding motivation for physical activity

\begin{tabular}{lcccccc}
\hline & $\begin{array}{c}\text { Early } \\
\text { Adolescents } \\
(\mathbf{1 1 - 1 4} \text { years) }\end{array}$ & $\begin{array}{c}\text { Middle } \\
\text { Adolescents } \\
(\mathbf{1 5}-\mathbf{1 8} \text { years })\end{array}$ & $\begin{array}{c}\text { Late } \\
\text { Adolescents } \\
(\mathbf{1 9 - 2 1} \text { years) }\end{array}$ & & & \\
\hline Factor & Mean \pm SD & Mean \pm SD & Mean \pm SD & F & Sig. & Eta square \\
\hline Sports Action with Friends & $13.22 \pm 3.08$ & $12.30 \pm 3.56$ & $13.31 \pm 3.88$ & 4.582 & .011 & .017 \\
Fitness and Health & $6.38 \pm 1.50$ & $6.37 \pm 1.80$ & $6.12 \pm 1.71$ & 1.346 & .261 & .005 \\
Social Status & $3.34 \pm .795$ & $3.52 \pm 1.11$ & $3.60 \pm .935$ & 3.274 & .039 & .012 \\
Popularity & $9.84 \pm 2.01$ & $10.04 \pm 2.58$ & $9.28 \pm 2.28$ & 5.060 & .007 & .018 \\
Energy Release & $3.52 \pm 1.08$ & $3.54 \pm 1.12$ & $4.09 \pm 1.27$ & 13.034 & .000 & .047 \\
\hline
\end{tabular}

* The mean difference is significant at the 0.05 level.

Participants were divided into three age groups: early (11-14 years old), middle (15-18 years old), and late (1921 years old) adolescence. Age group differences were calculated for the three age groups and are presented in Table 6. A one-way between-groups ANOVA was conducted to explore age-group differences for the five factors of perceived motivation for physical activity. Significant differences were found for four of the perceived motivations: sports action with friends $(\mathrm{F}(2,525)=4.58, \mathrm{p}=0.011)$, social status $(\mathrm{F}(2,525)=3.27, \mathrm{p}=0.039)$, popularity $(\mathrm{F}(2,525)=5.06, \mathrm{p}=0.007)$, and energy release $(\mathrm{F}(2,525)=13.03, \mathrm{p}=0.000)$. Fitness and health $(\mathrm{F}(2,525)=1.34, \mathrm{p}=0.000)$ did not show any significant differences across the three age groups. Differences among the groups were small, despite their significance. The effect sizes of the four factors were small, with eta squared being equal to $0.017,0.012,0.018$, and 0.047 , respectively. Post-hoc comparisons using Scheffé's test indicated that the difference for sports action with friends occurred between middle $(\mathrm{M}=12.30 \pm 3.56)$ and early $(\mathrm{M}=13.22 \pm 3.08)$ adolescence. Moreover, social status was a stronger motivating factor for physical activity during late adolescence $(\mathrm{M}=3.60 \pm 0.935)$ than middle $(\mathrm{M}=3.52 \pm 1.11)$ and early $(6.38 \pm 1.50)$ adolescence. However, popularity was a stronger motivating factor for physical activity during middle adolescence $(M=10.04 \pm 2.58)$ than early $(M=9.84 \pm 2.01)$ and late $(M=9.28 \pm 2.28)$ adolescence. Scheffé's post-hoc test also indicated that energy release is a much stronger motivating factor during middle adolescence $(\mathrm{M}=3.54 \pm 1.12)$ than early $(\mathrm{M}=4.09 \pm 1.27)$ or late $(\mathrm{M}=3.52 \pm 1.08)$ adolescence. No significant differences were found among the age groups regarding fitness and health as a motivating factor for physical activity.

Table 7. Level of achievements' differences regarding the motivation for physical activity

\begin{tabular}{|c|c|c|c|c|c|c|c|}
\hline & \multirow{2}{*}{$\begin{array}{l}\text { District Level } \\
(\mathrm{DL})(\mathrm{N}=253)\end{array}$} & \multirow{2}{*}{$\begin{array}{c}\text { Inter-District } \\
\text { Level (IDL) } \\
(\mathrm{N}=275)\end{array}$} & \multicolumn{5}{|c|}{ t-test for Equality of Means } \\
\hline & & & $\mathrm{t}$ & $\begin{array}{c}\text { Mean } \\
\text { Differenc } \\
\mathrm{e} \\
\end{array}$ & $\begin{array}{l}\text { Sig. (2- } \\
\text { tailed) }\end{array}$ & $\begin{array}{c}\text { Std. Error } \\
\text { Differenc } \\
\mathrm{e} \\
\end{array}$ & $\begin{array}{c}\text { Eta } \\
\text { squared }\end{array}$ \\
\hline $\begin{array}{l}\text { Sports Action with } \\
\text { Friends }\end{array}$ & $13.27 \pm 3.36$ & $12.59 \pm 3.68$ & 2.21 & .680 & .028 & .307 & 0.19 \\
\hline Fitness and Health & $6.53 \pm 1.51$ & $6.08 \pm 1.79$ & 3.14 & .457 & .002 & .145 & 0.27 \\
\hline Social Status & $3.28 \pm .748$ & $3.68 \pm 1.10$ & -4.83 & -.399 & .000 & .082 & 0.42 \\
\hline Popularity & $10.10 \pm 2.42$ & $9.41 \pm 2.19$ & 3.42 & .688 & .001 & .201 & 0.29 \\
\hline Energy Release & $3.53 \pm 1.13$ & $3.86 \pm 1.21$ & -3.27 & -.335 & .001 & .102 & 0.28 \\
\hline
\end{tabular}

Note: Cohen (1977) classifies .01 as a small effect, .06 as a medium effect, and .14 as a large effect.

Differences based on level of achievement were calculated using an independent-samples t-test for all five of the perceived motivational factors. The results are displayed in Table 7. Significant differences were found in all extracted sub-factors: sports action with friends DL $(\mathrm{M}=13.27 \pm 3.36)$ and IDL $(\mathrm{M}=12.59 \pm 3.68 ; \mathrm{t}(526)$ $=2.21, \mathrm{p}=0.028$, two-tailed $)$, fitness and health DL $(\mathrm{M}=6.53 \pm 1.51)$ and IDL $(\mathrm{M}=6.08 \pm 1.79 ; \mathrm{t}(526)=3.14$, $\mathrm{p}=0.002$, two-tailed $)$, social status DL $(\mathrm{M}=3.28 \pm 0.748)$ and IDL $(\mathrm{M}=3.68 \pm 1.10 ; \mathrm{t}(526)=-4.83, \mathrm{p}=0.000$, 
two-tailed), popularity DL $(\mathrm{M}=10.10 \pm 2.42)$ and $\mathrm{IDL}(\mathrm{M}=9.41 \pm 2.19 ; \mathrm{t}(526)=3.42, \mathrm{p}=0.001$, two-tailed $)$, and energy release DL $(\mathrm{M}=3.53 \pm 1.13)$ and $\operatorname{IDL}(\mathrm{M}=3.86 \pm 1.21 ; \mathrm{t}(526)=-3.27, \mathrm{p}=0.001$, two-tailed $)$.

\section{Discussion}

The risk of non-communicable diseases is the outcome of sedentary activities and has become a major concern among nations, including India (Lee et al., 2012). To address this crisis and sustain an active lifestyle, regular participation in sports and physical activities is recommended (Lee et al., 2012). The promotion of healthy habits such as regular exercise can greatly affect and influence one's personality. Embedding healthy habits into one's lifestyle during adolescence is essential for healthy entry into adulthood because this is regarded as a critical age for development. Therefore, sports participation is linked to motivation for predicting long-term participation in sports and physical activity.

The first aim of this study was to assess factors that underpin the motivation to participate in sports among Indian adolescent girls. Kondrič et al. (2013) investigated motivational differences among athletes using a crosscultural (Slovenia, Croatia, and Germany) study and yielded six factors on the PMQ. By contrast, this study yielded five factors that determined the broad dimension of sports participation motivation among adolescent girls in India. Kondrič et al. (2013) used a principal component analysis, whereas this study employed the robust maximum likelihood analysis because it possesses the unique feature of identifying minimum variance unbiased estimators as the sample size increases. The use of this method could be attributed to the 23 items and five factors that were retained in the analysis. The extracted five factors were estimated through structural equation modelling, which is a priority recommendation in Kondrič et al. (2013). The result of the CFA provided sound psychometric properties with an RMSEA of 0.054 and a CFI of 0.922 , including satisfactory reliability scores. In addition to these adequate psychometric properties, high reliability (i.e., internal consistency) scores for all factors indicated that the items were consistent within each factor and that the factors were consistent within the model, thereby permitting further meaningful analysis.

The secondary aim of this study was to investigate the differences in the level of motivation among girls in early, middle, and late adolescence (Steinberg, 1993). Small but significant differences were identified among the age groups with regard to three of the perceived motivational factors. Late adolescents showed higher means on the sub-factors of sports action with friends and social status factors compared with early and middle adolescents. Sports action with friends was the stronger motivational factor with respect to physical activity during late adolescence than in early and middle adolescence.

Participating in any sport or physical activity with peers (Macphail, Gorely, \& Kirk, 2003) has been shown to be enjoyable (Allender, Cowburn, \& Foster, 2006) and enhance engagement in an active lifestyle (Light et al., 2013). This participation could be the reason the "sports action with friends" factor showed a greater mean among late adolescents. Maturo and Cunningham (2013) also provided concrete evidence on how friendship influences physical activity during childhood. In other words, their study provided strong evidence showing how receiving encouragement from friends and engagement in physical activity with friends, along with those friends' own participation in physical activity, creates a strong relationship, maximizing children's participation in physical activity. Moreover, during late adolescence, individuals tend to engage in various gregarious activities that provide ample opportunities to develop sports and health-related performances. This factor included items such as "I like action," "I like teamwork," I like to do something I'm good at," "I want to learn new skills," "I like the excitement," "I want to improve my skills," and "I like to meet new friends." In the context of the descriptions of the extracted items, the current results are consistent with Maturo and Cunningham (2013) because their study recommended that exercise with peer groups should be imbedded firmly to enhance active living and lifelong healthy habits. Similarly, family and friends play a strong role in influencing decisions and maintaining participation in sports (Students of So285 Section 1, Fall 20141 \& Garcia, 2015). Our findings are also aligned with theories of adolescence, suggesting that the influence of one's social life and friendships 
becomes more significant for older adolescents than the family influences present during early childhood (Coleman \& Hendry, 1999).

The finding on late adolescents showing a higher social status mean level indicates that children seek special status in society as they grow based on their productive outputs. Social status refers to the perception of being admired or accepted by one's friends (Bukowski \& Hoza, 1989). This finding is highly attributed to athletes' profuse interest and motivation in sports participation and the success upon which they expect their performances should be valued and credited among their peers and in society (Goldberg \& Chandler, 1989; Kane, 1988; Thirer \& Wright, 1985). Additionally, the middle adolescent cohort reported a higher mean on the "popularity" factor. The term "social status" is likely often used interchangeably with popularity (Chase \& Machida, 2011). Finding popularity as a vital factor that determines motivation towards sports has high relevance regarding how athletic participation and its success become prevalent among middle adolescents. This finding supports Buchanan et al. (1976) and Kane (1988), who reported that sports play a substantial role in determining social status for girls and boys. However, their study also showed that boys are more inclined towards athletic participation than girls. Similarly, White (1995) examined collegiate male and female athletes and highlighted having higher athletic participation, which enhances competitiveness, career opportunities, and social status. Therefore, creating an in-depth gender-based understanding of athletic participation and its influence on popularity or social status requires additional research. Reports of higher means regarding the "energy release" factor among late adolescent athletes are attributed to athletes' extreme interest in and enjoyment of participating in sports. This study's findings support Students of So285 Section 1, Fall 20141 and Garcia's (2015) qualitative study in which one interviewee said: "I am very competitive when I play sports and pretty competitive in general. I like to keep playing sports to get rid of some of that competitive energy."

The third aim of this study was to investigate the differences in motivation for physical activity among adolescent athletes based on level of achievement (DL and IDL). Achievement level refers to the level of competition that the athletes represented. Therefore, IDL was the next competition status after the DL status. In other words, IDL is a higher level of competition than DL. In our study, DL adolescents showed higher means on the "sports action with friends," "fitness and health," and "popularity" factors.

Reports of a higher mean on the "sports action with friends" factor is highly attributable to the cohorts' playing status or achievement level. Belonging to a category of aspiring athletes, participants most likely enjoy playing with their friends, developing their skill and performance level, and analyzing their acquired skills with other mates (Allender et al., 2006). The fitness and health factor was also identified as a potential antecedent to participation in sports among DL adolescents. Although this cohort's achievement level was lower than that of IDL adolescents, participants might have higher intrinsic and extrinsic motivation levels for enhancing fitness and health, which is an irresistible determinant to win at higher levels of competitions with respect to abilities, skills, and social approval (Bosnar \& Balent, 2009). This reason could explain why fitness and health receives such a high score among DL athletes. This result also supports the finding of Allender et al. (2006), who indicated that adolescent athletes are highly obliged to the community setting; hence, during adolescence, they tend to have a greater competitive attitude towards challenging tasks in which they must maintain an ideal body image as a form of competition with their peers. Gaining popularity is the eternal essence of any competitive team in order to be more highly regarded by their peers, family, and society at large. DL adolescents are lower in competition status; hence, they most likely have a greater desire to gain popularity and compete with athletes who have higher achievement levels. Another consideration is that the research indicates that female adolescents possess a highly competitive mind that reflects a profuse desire to gain popularity through their level of skill and perfection at sports. This reason could explain why this factor showed a significant difference between the two cohorts.

IDL adolescents showed higher means on the "social status" and "energy release" factors, which were assumed to be strong motivating factors among DL adolescents. State and national levels are above inter-district 
competition. Therefore, it seems that this cohort is emerging in their fields of activity, from which they seek to uplift their social status and gain more popularity. From a psychological viewpoint, adolescents are more inclined to establish their own identity to increase efficiency in various aspects of decision-making (Ahmed, 2013, 2014; Murcia et al., 2010; Ahmed et al., 2014). This finding could explain why social status showed a significant mean difference between the two achievement levels.

Evidence shows that total involvement is inevitable when achieving a rewarding result in any desired activity. Intrinsic motivation is a key determinant of success. As those who participate in sports in the current cohort are just below state-level athletes, they are considered elite athletes. They most likely engage in strenuous sports training schedules that demand a significant release of energy to obtain their next goal/success in a determined event. Items comprising this factor, such as "I want to stay in shape" and "I want to get rid of energy," clearly relate to having an ideal body image as an important outcome of regular physical activity. In addition, excellent sports performance is related to significant sports skill practice, which ultimately undermines much of the energy release that athletes experience.

\section{Conclusions}

Female sports participation in India remains nascent because of various barriers, including gender discrimination, sexual abuse, and support from peers, family, and society. Therefore, sustaining motivation among girls who actively participate in sports is crucial to disseminate a positive message to adolescents who seek encouragement. It also serves as a platform to showcase their potential in the sports world. Nevertheless, it is important to observe the necessary social support and relationships with peers as the basic strategy in promoting sports participation for female adolescents. For female adolescents who come from less privileged areas, it appears that it is important to observe the factors of opportunities, social support, and relationships with peers. In addition, motivation is equally important for young female adolescents who want to participate in competitive sports. However, physical education and sports are often regarded as one and the same in India, making the conduct of a program challenging. Moreover, the subject of PE is not yet considered compulsory in India, which is highly attributable to the lack of low awareness of games and sports among people. Motivation as a construct has been the subject of substantial research among sports psychologists. Therefore, this study is highly relevant, especially as it included data on female adolescents from Assam regarding items that potentially determine their motivations. This study also explored the latent structure using an exploratory factor analysis to identify six factors that provided moderate interrelations among all of the factors, ranging between -0.026 and 0.501. The strongest correlation was shown between fitness and health and popularity. Moreover, the EFA factors retained for the CFA provided sound psychometric properties (e.g., CFI $=0.922$ and RMSEA $=0.054$ ).

\section{Competing Interests}

The authors declare no competing interests.

\section{Funding}

The authors received no direct funding for this research.

\section{Acknowledgment}

The authors extend their cordial thanks to all the participants in this study, who were immensely cooperative during the tests. The authors are also grateful to Mr. Bahniman Sarmah (Kendriya Vidyalaya, Nagaon) for his great support and cooperation with data capturing. The authors are also thankful to Miss Mehbiz Begum (Ramanujan, Junior College, Nagaon) and Shaheen Begum (Abeda Inamdar College, Pune University) for their great help with data entry. 


\section{REFERENCES}

Abder-Rahman, H. A. (2009). Hymen care for unmarried Muslim females: Role of the forensic consultant in gynecology interventions. Eastern Mediterranean Health Journal, 15, 864. DOI: https://doi.org/10.26719/2009.15.4.861

Ahmed, D. M. (2013). Comparative study of well-being, thought control, academic achievement and health related physical fitness of active and inactive adolescent school students. International Leisure Review, 2(2), 120-135. DOI: https://doi.org/10.6298/ILR.2013.2.2

Ahmed, D. M. (2014). Assessment of goal orientation among adolescent athletes with regard to their participation in recreation and leisure activities: A factor analysis approach. Journal of Physical Education and Sports Management, 2(2), 81-91. DOI: https://doi.org/10.15640/jpesmhttp://jpesm.com/

Ahmed, D. M., Ho, W. K. Y., \& Lee, J.-Y. (2016). Adolescence age transition and impact of physical activity on the perception of success, self esteem and well being. Journal of Physical Education and Sports, 124, 776-784. DOI: https://doi.org/10.7752/jpes.2016.03124

Ahmed, D. M., Mladenovic, M., Ho, W. K. Y., Lee, K. C., \& Khan, B. A. (2014). Exploring the perception of self-esteem among high school athletes. SportLogia Journal, 10(2), 81-88. DOI: https://doi.org/10.5550/sgia.141002.en.004A

Ahmed, D., Ho, W. K. Y., \& Lee, J.-Y. (2016). The adolescent age transition and the impact of physical activity on the perception of success, self-esteem and well-being. Journal of Physical Education and Sport, 16(124), 776-784.

Ahmed, D., Ho, W. K. Y., Van Niekerk, R. L., Morris, T., Elayaraja, M., Lee, K.-C., \& Randles, E. (2017). The self-esteem goal orientation and health related physical fitness of active and inactive adolescent students. Cogent Psychology, 4(1), 114. DOI: https://doi.org/10.1080/23311908.2017.1331602

Allender, S., Cowburn, G., \& Foster, C. (2006). Understanding participation in sport and physical activity among children and adults: A review of qualitative studies. Health Education Research, 21(6), 826-835. DOI: https://doi.org/10.1093/her/cyl063.

Australian Institute of Health and Welfare. (2010). Australia's health 2010. Australia's health series no. 12. Cat. no. AUS 122. Canberra, Australia: Australian Institute of Health and Welfare.

Bastos, A. S., Gonzalez, R., \& Marquez, S. (2006). Motives for participation in physical activity by Brazilian Adults. Perceptual and Motor Skills, 9(12), 358-367. DOI: https://doi.org/10.2466/pms.102.2.358-367

Bauman, A. E., Bull, F. C., Chey, T. et al. (2009). International physical activity prevalence estimates: Results from the International Prevalence Study in 20 countries. Int J Behav Nutr Phys Act, 6(21), 1-11. DOI: https://doi.org/10.1186/14795868-6-21

Beni, S., Fletcher, T., \& Chróinín, D. N. (2017). Meaningful experiences in physical education and youth sport: A review of the literature. Quest, 69(3), 291-312. DOI: https://doi.org/10.1080/00336297.2016.1224192

Bentler, P. M. (1995). EQS structural equations program manual. Encino, CA: Multivariate Software.

Bhandari, L. \& Chakraborty, M. (2014, October 19). Spatial poverty in Assam. Retrieved January 11, 2020, from https://www.livemint.com/Opinion/r0wWgeyhHBWfdKIfciWmTP/Spatial-poverty-in-Assam.html

Bollen, K. A. (1989) A new incremental fit index for general structural equation models. Sociological Methods \& Research, 17, 303-316.

Bosnar, K., \& Balent, B. (2009). Uvod u psihologiju sporta: Priručnik za sportske trenere /Introduction to psychology of sports: Manual for sports coaches/. Zagreb: Odjel za izobrazbu trenera Društvenog veleučilišta u Zagrebu i Kineziološki fakultet Sveučilišta u Zagrebu.

Browne, M. W., \& Cudeck, R. (1993). Alternative ways of assessing model fit. In K. A. Bollen \& J. S. Long (Eds.), Testing structural equation models (pp. 136-162). Newbury Park, CA: Sage.

Buchanan, H. T., Blankenbaker, J., \& Cotton, D. (1976). Academic and athletic ability as popularity factors in elementary school children. The Research Quarterly, 47, 320-325. DOI: https://doi.org/10.1080/10671315.1976.10615379

Bukowski, W. M., \& Hoza, B. (1989). Popularity and friendship: Issues in theory, measurement, and outcome. In T. J. Berndt \& G. W. Ladd (Eds.), Peer relationships in child development (pp. 15-45). New York: Wiley.

Byrne, B. M. \& Watkins, D. (2003). The issue of measurement invariance revisited. Journal of Cross-Cultural Psychology, 34, 155-175. DOI: https://doi.org/10.1177/0022022102250225

Calvo, T., Cervelló, E., Jiménez, R., Iglesias, D., \& Murcia, J. (2010). Using self-determination theory to explain sport persistence and dropout in adolescent athletes. Spanish Journal of Psychology, 13(2), 677-684. DOI: https://doi.org/10.1017/S1138741600002341

Chase, M. A., \& Dummer, G. M. (1992). The role of sports as a social status determinant for children. Research Quarterly for Exercise and Sport, 63, 418-424. DOI: https://doi.org/10.1080/02701367.2011.10599810 
Chase, M. A. \& Machida, M. (2011). The role of sport as a social status determinant for children. Research Quarterly for Exercise and Sport, 82(4), 731-739. DOI: https://doi.org/10.1080/02701367.2011.10599810.

Clark, M. I., Spence, J. C., \& Holt, N. L. (2011). In the shoes of young adolescent girls: Understanding physical activity experiences through interpretive description. Qualitative Research in Sport, Exercise and Health, 3, 193-210. DOI: https://doi.org/10.1080/2159676X.2011.572180

Cohen, J. (1977). Statistical power analysis for the behavioral sciences. New York: Routledge.

Coleman, J., \& Hendry, L. (1999). The nature of adolescence. London: Routledge

Debono, M., \& Cachia, E. (2007). The impact of diabetes on psychological well-being and quality of life: The role of patient education. Psychology, Health and Medicine, 12(5), 545-555. DOI: https://doi.org/10.1080/13548500701235740

Deci, E., \& Ryan, R. (1985). Intrinsic motivation and self-determination in human behavior. New York: Plenum.

Deci, E. L., \& Ryan, R. M. (1985). Intrinsic motivation and self-determination in human behaviour (2nd ed.). New York: Plenum Press.

Deci, E. L., \& Ryan, R. M. (2000). The "what" and "why" of goal pursuits: Human needs and the self determination of behaviour. Psychological Inquiry, 11(4), 227-268. Retrieved June 22, $2020 \quad$ from http://www.tandf.co.uk/journals/journal.asp?issn=1047-840X

Eime, R. M., Harvey, J. T., Sawyer, N. A., Craike, M. J., Symons, C. M., \& Payne, W. R. (2016). Changes in sport and physical activity participation for adolescent females: A longitudinal study. BMC Public Health, 16, 533. DOI: http://doi.org/10.1186/s12889-016-3203-x

Environment, Communications, Information Technology and the Arts References Committee. (2006). About time! Women in sport and recreation in Australia. Canberra, Australia: Commonwealth of Australia.

Fenton, S. A. M., Duda, J. L., Appleton, P. R., \& Barrett, T. G. (2017). Empowering youth sport environments: Implications for daily moderate-to-vigorous physical activity and adiposity. Journal of Sport and Health Science, 6(4), 423-433. Doi: https://doi.org/10.1016/j.jshs.2016.03.006.

Field, A. (2000). Discovering statistics using SPSS for Windows. London: SAGA.

Fraser-Thomas, J., Cote, J., \& Deakin, J. (2008). Examining adolescent sport drop-out and prolonged engagement from a developmental perspective. Journal of Applied Sport Psychology, 20, 318-333. DOI: https://doi.org/10.1080/10413200802163549

Gill, D. L., Gross, J. B., \& Huddleston, S. (1983). Participation motivation in youth sports. International Journal of Sport Psychology, 14, 1-14.

Goldberg, A. D., \& Chandler, T. J. L. (1989). The role of athletics: The social world of high school adolescents. Youth and Society, 21, 238-250. DOI: https://doi.org/10.1177/0044118X89021002006

Guttman, A. (1991). Women's sports: A history. New York, NY: Columbia University Press.

Ho, W. K. Y., Ahmed, D. M., D’Amico, R. D., Ramos, A., Ferreira, E. L., Ferreira, M. B. R., Amaral, S. C. F., Gurrola, O. C., Diaz, G. B., Ramos, A., Hoyos, L. A., Jasmin, A., Duque, A. R., Huang, F., \& Wong, B. (2018). Quality physical education - Perception and Latin American perspective. Revista Brasileira de Ciências do Esporte (RBCE) (Brazilian Journal of Sport Sciences), 40(4), 361-369. DOI: https://doi.org/10.1016/j.rbce.2018.05.006

Ho, W. K. Y., Ahmed, D. M., Keh, C. N., Khoo, S., Tan, C., Dehkordi, R. M., Gallardo, M., Lee, K., Yamaguchi, Y., Wang, J., Liu, M., \& Huang, F. (2017a). Professionals' perception on quality physical education learning in selected Asian cities. Cogent Education, 4(1408945), 1-17. DOI: https://doi.org/10.1080/2331186X.2017.1408945

Ho, W. K. Y., Ahmed, D. M., Keh, N. C., Khoo, S., Tan, C., Dehkordi, M. R., Gallardo, M., Lee, K. C., Yamaguchi, Y., Tao, Y., Shu, C., Huang, F., \& Wong, B. (2019a). Towards developing and validating quality physical education in schools - The Asian physical education professionals' voice. PLoS ONE 14(8): e0218158. DOI: https://doi.org/10.1371/journal.pone.0218158

Ho, W. K. Y., Ahmed, D. M., Van Niekerk, R. L., D’amico, R. L. D, Branislav, A., Dinold, M., Holzweg, M., Morris, T., Wang, J., Huang, F., \& Wong, B. (2019b). Development of an instrument to assess perception of quality physical education (QPE) among European professionals. South African Journal for Research in Sport, Physical Education and Recreation, 41(1), 31-49. https://journals.co.za/content/journal/10520/EJC-14fdd81ac8

Ho, W. K. Y., Ahmed, D. M., Leong, C. I., Patrick, I. P., Huang, F., \& Chen, J. (2019c). An assessment of Body Mass Index and sensitive period for overweight development in Macao students at primary school age. Anthropological Review, 82(1), 29-41. DOI: https://doi.org/10.2478/anre-2019-0003

Humbert, M. L., Chad, K. E., Bruner, M. W., Spink, K. S., Muhajarine, N., Anderson, K. D., et al. (2008). Using a naturalistic ecological approach to examine the factors influencing youth physical activity across grades 7 to 12 . Health Education \& Behavior, 35(2), 158-173. DOI: https://doi.org/10.1177/1090198106287451 
Husan, H. (2015). A study on female and sports condition in India. Journal of Sports Technology and Human Engineering, 1(8), 1-9. https://ijosthe.com/index.php/ojssports/article/view/14

Iannotti, J. R., Chen, R., Kololo, H., Petronyte, G., Haug, E., \& Roberts, C. (2012). Motivations for adolescent participation in leisure-time physical activity: International differences. Journal of Physical Activity and Health, 9, 106-114. DOI: https://doi.org/10.1123/jpah.10.1.106

Iso-Ahola, S. E. \& St. Clair, B. S. (2000). Toward a theory of exercise motivation. Quest, 52(2), 131-147.

Kane, M. J. (1988). The female athletic role as a status determinant within the social systems of high school adolescents. Adolescence, 23, 253-264.

Khandare, D. R. B. (2016). A study of physical tutoring \& sporting in India. IOSR Journal of Sports and Physical Education, 3(1), 18-26. DOI: https://doi.org/10.9790/6737-03020103

Kondrič, M., Sindik, J., Furjan-Mandic, G., \& Bernd Schiefler, B. (2013). Participation motivation and student's physical activity among sport students in three countries. J. Sports Sci Med, 12(1), 10-8.

Layak, S., \& Aravind, I. (2017, July 30). This is the grim reality women have to face to make it big in Indian sports. The Economic Times. Retrieved June 22, 2020 from https://economictimes.indiatimes.com/news/sports/this-is-the-grimreality-women-have-to-face-to-make-it-big-in-indian-sports/articleshow/59826287.cms? from=mdr

Lee, I.-M., Shiroma, E. J., Lobelo, F., Puska, P., Blair, S. N., \& Katzmarzyk, P. T. for the Lancet Physical Activity Series Working Group. (2012). Impact of physical inactivity on the world's major non-communicable diseases. The Lancet, 380(9838), 219-229. DOI: https://doi.org/10.1016/S0140-6736(12)61031-9.

Light, R. L., Harvey, S., \& Memmert, D. (2013). Why children join and stay in sports clubs: Case studies in Australian, French and German swimming club. Sport, Education and Society, 18(4), 550-566. DOI: https://doi.org/10.1080/13573322.2011.594431

Lonsdale, C., Rosenkranz, R., Sanders, T., Peralta, L., Bennie, A., Jackson, B., \& Lubans, D. (2013). A cluster randomized controlled trial of strategies to increase adolescents' physical activity and motivation in physical education: Results of the Motivating Active Learning in Physical Education (MALP) trial. Preventive Medicine, 57(5), 696-702. DOI: https://doi.org/10.1016/j.ypmed.2013.09.003.

Lonsdale, C., Sabiston, C. M., Raedeke, T. D., Ha, A. S., \& Sum, R. K. (2009). Self-determined motivation and students' physical activity during structured physical education lessons and free choice. Preventive Medicine, 48(1), 69-73. DOI: https://doi.org/10.1016/j.ypmed.2008.09.013.

Lutz, R. S., Karoly, P., \& Okun, M. A. (2008). The why and the how of goal pursuit: Self-determination, goal process cognition, and participation in physical exercise. Psychology of Sport \& Exercise, 9, 559-575. DOI: https://doi.org/10.1016/j.psychsport.2007.07.006

Macphail, A., Gorely, T., \& Kirk, D. (2003). Young people's socialization into sport: A case study of an athletics club. Sport, Education and Society, 8(2), 251-267. DOI: https://doi.org/10.1080/13573320309251

Marsh, H. W., Wen, Z., \& Hau, K. T. (2004). Structural equation models of latent interactions: Evaluation of alternative estimation strategies and indicator construction. Psychological Methods, 3, 275-300. DOI: https://doi.org/10.1037/1082989X.9.3.275

Matsumoto, H. \& Takenaka, K. (2004). Motivational profiles and stages of exercise behavior change. International Journal of Sport and Health Science, 2, 89-96. DOI: https://doi.org/10.5432/ijshs.2.89

Maturo, C. C. \& Cunningham, S. A. (2013). Influence of friends on children's physical activity: A review. Am J Public Health, 103(7):e23-38. DOI: https://doi.org/10.2105/AJPH.2013.301366.

Murcia, J. A. M, Coll, D. G-C., Martin-Albo, J., \& Gimeno, E. C. (2010). Motivation and performance in physical education: An experimental test. Journal of Sports Science and Medicine, 9, 79-85.

Nicholls, J. G. (1989). The competitive ethos and democratic education. Cambridge, MA: Harvard University Press.

Nielse, G., Pfister, G., \& Andersen, B. L. (2011). Gender differences in the daily physical activities of Danish school children. European Physical Education Review, 17(1), 69-90. DOI: https://doi.org/10.1177/1356336X11402267

Pfaeffli, L. \& Gibbons, S. L. (2010). Girls getting active: Exploring a physical education program tailored to young women. PHEnex Journal, 2(3), 1-21.

Pfister, G. (2017). Gender, gender equality and women's sport: Theories and practices. In R. L. de DiAmico, T. Benn, \& G. Pfister (Eds.), Women and sport in Latin America (pp. 32-54). London: Routledge.

Piri, M., Mahmoudi, A., Gol, M., \& Talebi, R. (2014). The comparison of Reiss motivation in sport participation between girl and boy students. Indian Journal of Fundamental and Applied Life Sciences, 4(S4), 3816-3824. 
Sánchez, G. F. L., Ahmed, D. M., Balsalobre, F. J. B., Sánchez, L.L., and Suárez, A.D. (2016). Level of habitual physical activity in 8-9 years old schoolchildren from Spain and India. MHSalud-Revista en Cienciasdel Movimiento Humano y la Salud, 12(2), 1-10. DOI: https://doi.org/10.15359/mhs.12-2.3

Sarrazin, P. G., Boiché, J. C. S., \& Pelletier, L. G. (2007). A self-determination approach to sport dropout. In M. Hagger $\&$ N. Chatzisarantis (Eds.), Intrinsic motivation and self-determination in exercise and sport (pp. 229-241). Champaign, Illinois: Human Kinetics Publisher.

Scheerder, J., Thomis, M., Vanreusel, B., Lefevre, J., Renson, R., Eynde, V. B., \& Beunen, P. G. (2006). Sports participation among females from adolescence to adulthood: A longitudinal study. International Review for the Sociology of Sport, 41(3-4), 413-430. DOI: https://doi.org/10.1177/1012690207077702

Shen, B., McCaughtry, N., Martin, J. J., Fahlman, M., \& Garn, A. C. (2012). Urban high-school girls' sense of relatedness and their engagement in physical education. Journal of Teaching in Physical Education, 31(3), 231-245.

Sherar, L. B., Esliger, D. W., Baxter-Jones, A. D. G., \& Tremblay, M. S. (2007). Age and gender differences in youth physical activity: Does physical maturity matter? Medicine and Science in Sports and Exercise, 39(5), 830-835. DOI: https://doi.org/10.1249/mss.0b013e3180335c3c

Sherar, L. B., Gyurscsik, N. C., Humbert, L. M., Dyck, R. F., Fowler-Kerry, S., \& Baxter-Jones, A. D. G. (2008). Activity barriers in girls (8-16) based on grade and maturity status. Medicine and Science in Sports and Exercise, 41, 87-95. DOI: https://doi.org/10.1249/MSS.0b013e31818457e6

Singh, K. (2016). Role of physical education and sports in Indian prospective: An overview. International Journal of Physical Education, Sports and Health, 3(5), 280-282.

Steinberg, L. D. (1993). Adolescence (3rd ed.). New York: McGraw-Hill.

Strel, J., \& Sila, B. (2010). Športne dejavnosti slovenske mladine med 15. in 18. letom starosti [Sport activity of Slovenian adolescents aged between 15 and 18]. Šport, 58, 124-129 (In Slovenian: English abstract).

Strong, W. B., Malina, R. M., Blimki, C. J., et al. (2005). Evidence based physical activity for school-age youth. Journal of Pediatrics, 146(6), 732-737. DOI: https://doi.org/10.1016/j.jpeds.2005.01.055

Students of So285 Section 1, Fall 20141 \& Garcia, C. A. (2015). Understanding high school students' sports participation. Sports Science Review, 24(3-4), 121-144. DOI: https://doi.org/10.1515/ssr-2015-0012

Teixeira, P. J., Carraça, E. V., Markland, D., Silva, M. N., \& Ryan, R. M. (2012). Exercise, physical activity, and selfdetermination theory: A systematic review. International Journal of Behavioral Nutrition and Physical Activity, $9,78$. DOI: https://doi.org/10.1186/1479-5868-9-78

Thirer, J., \& Wright, S. D. (1985). Sport and social status for adolescent males and females. Sociology of Sport Journal, 2, 164-171. DOI: https://doi.org/10.1123/ssj.2.2.164

Trembath, E. M., Szabo, A., \& Baxter, M. J. (2002). Participation motives in leisure center physical activities. Athletic Insight: The Online Journal of Sports Psychology, 4(3). Retrieved from http://www.athleticinsight.com/Vol4Iss3/LeisureCenterParticipationMotives.htm

Trost, S. G., Rosencrantz, R. R., \& Dzewaltowski, D. (2008). Physical activity levels among children attending after school programs. Medicine and Science in Sports and Exercise, 40, 622-629. DOI: https://doi.org/10.1249/MSS.0b013e318161eaa5

United Nations Division for the Advancement of Women, Department of Economic and Social Affairs. (2007). Women 2000 and beyond: Women, gender equality and sport (p. 15). New York, NY: United Nations Entity for Gender Equality and the Empowerment of Women (UN Women).

United Nations, Department of Economic and Social Affairs, Population Division. (2015). World population prospects: The 2015 revision, key findings and advance tables. Working Paper No. ESA/P/WP.241. New York, NY: United Nations.

Ward, J., Wilkinson, C., Vincent, S., \& Prusak, K. A. (2008). Effects of choice on student motivation and physical activity behavior in physical education. Journal of Teaching in Physical Education, 27(3), 385-398. DOI: https://doi.org/10.1123/jtpe.27.3.385

White, S. A. (1995). The perceived purposes of sport among male and female intercollegiate and recreational sport participants. International Journal of Sport Psychology, 26, 490-502.

Whitehead, J., Andrée, K., \& Lee, M. L. (2004) Achievement perspectives and perceived ability: How far do interactions generalize in youth sport? Psychology of Sport and Exercise, 5, 291-317. DOI: https://doi.org/10.1016/S14690292(03)00016-5

Whitehead, S., \& Biddle, S. (2008). Adolescent girls' perceptions of physical activity: A focus group study. European Physical Education Review, 14, 243-262. DOI: https://doi.org/10.1177/1356336X08090708 
World Health Organization. (2008). Inequalities in young people's health: International report from the HBSC 2006/08 survey. WHO Policy Series: Health Policy for Children and Adolescents, Issue 5. Copenhagen, Denmark: World Health Organization.

Yesudian, C. A., Grepstad, M., Visintin, E., \& Ferrario, A. (2014). The economic burden of diabetes in India: A review of the literature. Global Health Journal, 10(80), 2-18. DOI: 10.1186/s12992-014-0080-x

Zahariadis, P. N. \& Biddle, S. J. H. (2000). Goal orientations and participation motives in physical education and sport: Their relationships in English schoolchildren. Athletic Insight, 2(1), 1-12. DOI: https://doi.org/10.7752/jpes.2013.03074

Zahariadis, P. N., Tsorbatzoudis, H., \& Grouios, G. (2005). The Sport Motivation Scale for Children: Preliminary analysis in physical education classes. Perceptual and Motor Skills, 101, 43-54. DOI: https://doi.org/10.2466/PMS.101.5.43-54

\section{AUTHOR'S ADDRESS:}

Md. Dilsad Ahmed

College of Public Health and Human Sciences

Oregon State University

223D Langton Hall

Corvallis, OR 97331-3303

USA

E-mail:ahmedm@oregonstate.edu

Received: 7 February 2020; Accepted: 3 June 2019 